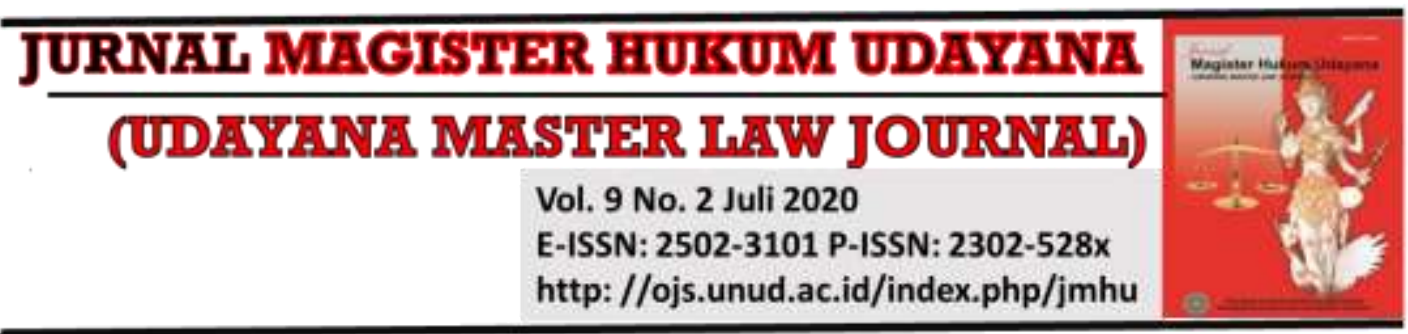

\title{
Akibat Hukum Pelelangan Tanah Yang Menjadi Objek Sewa Menyewa
}

\author{
Johanes Maria Vianney Graciano ${ }^{1}$
}

${ }^{1}$ Program Studi Magister Ilmu Hukum, Universitas Udayana, E-mail: jmv.graciano@gmail.com

\begin{tabular}{l}
\hline Info Artikel \\
\hline Masuk: 22 Maret 2018 \\
Diterima: 17 Juli 2020 \\
Terbit: 31 Juli 2020 \\
Keywords: \\
Lease Agreement; Auction; \\
Legal Remedy \\
\\
\\
Kata kunci: \\
Perjanjian Sewa Menyewa; \\
Lelang; Upaya Hukum \\
Corresponding Author: \\
Johanes Maria Vianney \\
Graciano, Email: \\
jmv.graciano@gmail.com \\
DOI: \\
10.24843/JMHU.2020.v09.i02. \\
p.08
\end{tabular}

\begin{abstract}
Leasing is one of methods to possess the land in Indonesia, which sometimes a legal dispute can arise during its implementation. One of such legal disputes is an auctioning of lease object, which being a case in civil case with registration number387/Plw/2011/PN.Dps. This dispute caused by a landlord's action who's without a good faith put a lease object under a mortgage as a collateral for his debt to third party and then he failed to settle such debt. The purpose of this research is to know the legal effect of auction of the lease object specifically concerning the existence of the lease agreement. The method using in this journal is normative legal research to analyze the legal effect of the auction to the existing land lease agreement and the possible legal remedy to undertake by the party who suffered a damage. Auctioning and transferring of lease object ownership shall not terminate the lease agreement as long as the lease agreement was made prior to the transferring of ownership except the agreement stipulates differently. In the agreement, one of parties who suffered damage has right to undertake a legal remedy to protect its right and interest.
\end{abstract}

Abstrak
Sewa menyewa merupakan salah satu cara penguasaan atas
tanah di Indonesia yang dalam pelaksanaannya sering
mengakibatkan adanya sengketa. Salah satu sengketa hukum
yang terjadi adalah pelelangan atas tanah yang sebelumnya telah
menjadi objek perjanjian sewa menyewa, yang menjadi materi
dalam perkara perdata Nomor 378/Plw/2011/PN.Dps.
Permasalahan ini muncul akibat perbuatan pemilik tanah yang
tanpa itikad baik membebani tanah yang telah disewakannya
dengan hak tanggungan sebagai jaminan pelunasan hutangnya
kepada pihak ketiga dan selanjutnya tidak mampu melunasi
hutangnya. Tujuan dari penelitian ini adalah untuk mengetahui
akibat hukum dari adanya pelelangan objek sewa menyewa
khususnya mengenai kelangsungan perjanjian sewa menyewa itu
sendiri. Metode yang digunakan dalam penulisan jurnal ini
adalah penelitian hukum normatif yang menganalisis akibat
hukum pelelangan tanah terhadap kelangsungan perjanjian sewa
menyewa serta upaya hukum yang dapat diambil oleh pihak yang
merasa dirugikan. Pelelangan dan pengalihan kepemilikan atas
suatu objek sewa tidak akan mengakhiri perjanjian sewa
menyewa, sepanjang perjanjian sewa itu dibuat lebih awal
daripada pengalihan hak kecuali diperjanjikan berbeda oleh para


pihak. Pihak yang merasa haknya dirugikan dalam suatu perjanjian berhak mengambil upaya hukum untuk melindungi hak dan kepentingannya.

\section{Pendahuluan}

Pulau Bali sebagai destinasi wisata di Indonesia mempunyai daya tarik yang tinggi bagi orang asing, baik unuk melakukan liburan, penanaman modal di bidang jasa yang terkait dengan pariwisara maupun untuk tinggal dan menetap di Bali. Bagi orang asing yang berkeinginan untuk tinggal dan menetap di Indonesia, maka diperlukan penguasaan atas tanah sebagai sarana tempat tinggal. ${ }^{2}$

Penguasaan tanah di Indonesia dapat dilakukan dengan berbagai cara, antara lain dengan hak milik, hak guna bangunan, hak guna usaha, hak pakai dan hak sewa. Bentuk-bentuk penguasaan tanah ini telah diatur dalam peraturan perundangundangan, yaitu Undang-Undang Nomor 5 Tahun 1960 tentang Peraturan Dasar PokokPokok Agraria.

Bentuk penguasaan hak atas tanah yang cukup banyak terjadi di Bali adalah dengan menggunakan hak sewa. Penguasaan tanah dengan hak sewa banyak digunakan oleh orang asing dan lebih aman digunakan daripada menggunakan metode perjanjian nominee. Adapun perjanjian nominee sebenarnya merupakan sebuah perjanjian yang dimana seolah-olah seorang asing mempunyai hak milik atas tanah di Indonesia dengan menggunakan nama orang Indonesia, sehingga tidak menyalahi ketentuan perundangundangan. Hal ini dapat dianggap sebagai suatu penyelundupan hukum. ${ }^{3}$

Penguasaan hak sewa atas tanah di Indonesia dalam praktiknya diatur dalam sebuah perjanjian antara pemilik tanah dan penyewa. Secara umum perjanjian sewa menyewa diatur dalam Buku III Kitab Undang-Undang Hukum Perdata (selanjutnya disebut sebagai KUH Perdata).

Perjanjian sewa menyewa menimbulkan hak dan kewajiban bagi masing-masing pihak, yang mana kewajiban pokok dari pemilik objek atau pihak yang menyewakan adalah menyerahkan barang atau objek sewa, sedangkan kewajiban dari penyewa adalah membayar harga sewa. Oleh karena masing-masing pihak sama-sama mempunyai hak dan kewajiban satu terhadap yang lain yang saling terkait, maka sewa menyewa termasuk perjanjian timbal balik.

Salah satu permasalahan yang muncul dalam pelaksanaan sewa menyewa ini adalah adanya perbuatan wanprestasi dari pihak yang menyewakan. Setelah perjanjian sewa menyewa dengan objek berupa tanah disepakati, pihak yang menyewakan mengagunkan objek sewa sebagai jaminan pelunasan utangnya tanpa pemberitahuan kepada penyewa. Permasalahan hukum muncul ketika pihak yang menyewakan tidak mampu membayar utangnya dan mengakibatkan objek sewa harus dijual lelang.

${ }^{2}$ Prahandari, N. M. I. (2014). Penguasaan Hak Milik Atas Tanah Milik Warga Indonesia Oleh Warga Negara Asing Dengan Akta Notaris/Pejabat Pembuat Akta Tanah (Studi Kasus). Tesis, Program Pasca Sarjana Magister Kenotariatan, Universitas Udayana.

${ }^{3}$ Sancaya, I. W. W. (2013). Kekuatan Mengikat Perjanjian Nominee Dalam Penguasaan Hak Milik Atas Tanah. Jurnal Magister Hukum Udayana 2(3). doi.org/10.24843/JMHU.2013.v02.i03.p10, h.1. 
Berdasarkan latar belakang masalah dalam penelitian ini, maka ada 2 (dua) rumusan masalah yang dapat dibahas dalam jurnal ini. Permasalahan yang pertama mengenai bagaimana prosedur pelaksanaan lelang Sertifikat Hak Tanggungan dan untuk permasalahan yang kedua adalah bagaimana akibat hukum dari adanya pelelangan tersebut terhadap pelaksanaan perjanjian sewa menyewa.

Pokok permasalahan yang dibahas dalam jurnal ini masih bersifat orisinalitas, karena belum ada jurnal lain yang secara khusus membahas permasalahan di atas. Beberapa jurnal hanya membahas mengenai perjanjian sewa menyewa atau hak tanggungan, antara lain:

1. Jurnal dengan judul Penarikan Barang Yang Menjadi Objek Sewa Beli Dalam Hal Pembeli Melakukan Wanprestasi, yang ditulis oleh Putu Sumiasi yang pokok bahasannya adalah hak kreditor untuk menarik objek sewa beli apabila pembeli melakukan wanprestasi. ${ }^{4}$

2. Jurnal yang berjudul Pelaksanaan Perjanjian Tanah Hak Milik Bersama Sebagai Agunan Dalam Kredit di Bank Berdasarkan Undang-Undang Nomor 4 Tahun 1996 tentang Hak Tanggungan Atas Tanah Berserta Benda-Benda Yang Berkaitan Dengan Tanah. Jurnal ini ditulis oleh I Made Sudirga dengan pokok permasalahan adalah akibat hukum dari menjaminkan tanah hak milik Bersama sebagai agunan dalam perjanjian kredit di bank. ${ }^{5}$

3. Jurnal dengan judul Perlindungan Hukum Pemegang Hak Tanggungan Yang Objeknya Dikuasai Pihak Ketiga Berdasarkan Perjanjian Sewa Menyewa, yang ditulis oleh Dian Pertiwi dengan pokok permasalahan adalah perlindungan hukum bagi pemegang hak tanggungan yang objeknya kemudian disewakan kepada pihak ketiga dengan persetujuan kreditor serta bentuk perlindungan hukum bagi penyewa objek hak tanggungan. ${ }^{6}$

Perbedaan kekhususan antara jurnal ini dibandingkan dengan ketiga jurnal di atas adalah pada titik berat pembahasannya, dimana jurnal ini membahas dan menganalisis aspek hukum dari akibat hukum peralihan hak sewa atas objek sewa dan akibatnya terhadap perjanjian sewa menyewa. Apalagi hal yang menarik dari permsalahan di atas adalah adanya unsur wanprestasi dari pemilik tanah sebagai pihak yang menyewakan pada proses peralihan hak yang tentu mempengaruhi hakhak dari penyewa.

Adapun tujuan diadakannya penelitian ini adalah sebagai berikut adalah untuk mengetahui dan memahami mengenai pengaturan pelaksanaan perjanjian sewa

\footnotetext{
${ }^{4}$ Sumiasi, P. (2013). Penarikan Barang Yang Menjadi Objek Sewa Beli Dalam Hal Pembeli Sewa Wanprestasi. Jurnal Magister Hukum Udayana 2(3). doi.org/10.24843/JMHU.2013.v02.i03.p06, h. 7.

${ }^{5}$ Sudirga, I. M. (2017). Pelaksanaan Perjanjian Tanah Hak Milik Bersama Sebagai Agunan Dalam Kredit Di Bank Berdasarkan Undang-Undang Nomor 4 Tahun 1996 tentang Hak Tanggungan Atas Tanah Beserta Benda-Benda Yang Berkaitan Dengan Tanah. Jurnal Magister Hukum Udayana 6(2). doi.org/10.24843/JMHU.2017.v06.i02.p10, h. 263.

${ }_{6}^{6}$ Pertiwi, D. (2013). Perlindungan Hukum Pemegang Hak Tanggungan Yang Objeknya Dikuasai Pihak Ketiga Berdasarkan Perjanjian Sewa Menyewa. Calyptra. journal.ubaya.ac.id/index.php/jimus/article/view/729, h.3-4.
} 
menyewa setelah objeknya dijual lelang. Selain itu, penelitian ini juga bertujuan untuk mengetahui dan memahami cara dan upaya yang dapat ditempuh oleh penyewa untuk mempertahankan hak-haknya.

Permasalahan yang dibahas dalam jurnal ini juga cukup penting dalam perkembangan dan penerapan hukum perjanjian di Indonesia, khususnya dalam perlindungan hukum penyewa dan pembebanan jaminan kebendaan berupa hak tanggungan yang sangat banyak terjadi di Bali.

\section{Metode Penelitian}

Jenis penelitian ini menggunakan metode penelitian hukum normatif, yaitu penelitian terhadap aspek hukum suatu permasalahan yang dilakukan dengan cara menganalisi bahan hukum primer dan bahan hukum sekunder untuk kemudian dihubungkan dengan permasalahan hukum yang ada. ${ }^{7}$ Pendekatan yang digunakan dalam penelitian ini adalah pendekatan kasus (case approach) yang menitikberatkan pada argumentasi hukum yang dibangun dalam perspektif kasus konkret yang terjadi.

Penelitian tentang Akibat Hukum Penjualan Lelang Objek Sewa Menyewa Terhadap Pelaksanaan Perjanjian Sewa Menyewa yang didasarkan pada suatu studi kasus atas Putusan Pengadilan Negeri Denpasar No. 387/Pdt.Plw/2011/PN.Dps dapat dikualifikasikan sebagai penelitian hukum normatif, karena penelitian ini menitikberatkan pada argumentasi hukum yang dibangun oleh hakim dalam pertimbangan putusannya dan akibat hukum terhadap pelaksanaan suatu perjanjian sewa menyewa yang objeknya telah dijual lelang.

\section{Hasil dan Pembahasan}

\subsection{Prosedur Eksekusi Lelang Hak Tanggungan}

Dalam Hukum Indonesia, Hak Tanggungan diatur dalam Undang-Undang Nomor 4 Tahun 1996 tentang Hak Tanggungan Atas Tanah Beserta Benda-Benda Yang Berkaitan Dengan Tanah (selanjutnya disebut dengan UU Hak Tanggungan). Adanya UU Hak Tanggungan mengakibatkan ketentuan mengenai hypotheek yang berkaitan dengan tanah sebagaimana diatur dalam Buku II KUH Perdata menjadi tidak berlaku lagi dan juga lembaga hak tanggungan sudah diamanatkan dalam UU Pokok Agraria. ${ }^{8}$

Hak Tanggungan merupakan salah satu bentuk jaminan kebendaan di Indonesia. Eksistensi jaminan kebendaan merupakan instrument yang sangat penting dalam melindungi hak-hak kreditor sebagai penyedia dana yang akan diberikan dalam bentuk pinjaman kepada debitor. Jaminan ini memberikan perlindungan kepada

\footnotetext{
${ }^{7}$ Hartono, C.F.G. Sunaryati. (2006). Penelitian Hukum di Indonesia Pada Akhir Abad Ke-20. Bandung: Alumni, h.140.

${ }^{8}$ Sjahdeini, S. R. (2006). Hak Tanggungan Asas-Asas, Ketentuan-Ketentuan Pokok Dan MasalahMasalah Yang Dihadapi Perbankan. Surabaya: Airlangga University Press, h.1.
} 
kreditor untuk mendapatkan pelunasan apabila di kemudian hari debitor melakukan wanprestasi. ${ }^{9}$

Hak Tanggungan dalam sistem hukum Indonesia diklasifikasikan sebagai jaminan khusus, yaitu suatu perjanjian jaminan kebendaan yang dibuat secara khusus antara kreditor dengan debitor, yang objeknya adalah benda-benda tertentu milik debitor dan diperuntukkan untuk menjadi jaminan pelunasan kepada kreditor tertentu saja. Adanya jaminan khusus membuat kreditor mempunyai keiistimewaan atau privilege dalam hal pelunasan utangnya. Hal ini berbeda dengan jaminan umum sebagaimana diatur dalam Pasal 1131 dan Pasal 1132 KUH Perdata, dimana dalam jaminan umum setiap kreditor mempunyai kedudukan hukum yang sama. ${ }^{10}$

Hak Tanggungan sebagai jaminan kebendaan akan melahirkan hak kebendaan bagi pemegangnya. Hak kebendaan mempunyai sifat droit de suit (hak mengikuti) dan droit de preference (hak terlebih dahulu). Droit de suit dapat didefinisikan hak kebendaan akan tetap mengikuti benda tersebut ke tangan siapapun benda itu berada, sedangkan droit de preference artinya pemegang jaminan kebendaan akan mendapat prioritas untuk didahulukan pembayarannya. ${ }^{11}$ Asas droit de preference ini akan terlihat pada saat terjadinya eksekusi Hak Tanggungan melalui pelelangan.

Kajian ini menggunakan Peraturan Menteri Keuangan Nomor 93/PMK.06/2010 tentang Petunjuk Pelaksanaan Lelang (selanjutnya disebut Peraturan Petunjuk Lelang) sebagai pedoman oleh karena pada saat permasalahan tersebut terjadi, Peraturan Petunjuk Lelang adalah peraturan hukum yang berlaku. Dalam ketentuan Peraturan Petunjuk Lelang tersebut, lelang diartikan sebagai penjualan barang yang terbuka untuk umum dengan penawaran harga secara tertulis dan/atau lisan yang semakin meningkat atau menurun untuk mencapai harga tertinggi, yang didahului dengan Pengumuman Lelang.

Selain pengertian tentang lelang, dalam Peraturan Petunjuk Lelang tersebut juga ditegaskan mengenai lelang eksekusi. Sesuai dengan istilahnya, lelang eksekusi bertujuan untuk melaksanakan putusan/penetapan pengadilan, dokumen-dokumen lain yang dipersamakan dengan itu, dan/atau melaksanakan ketentuan dalam peraturan perundang-undangan. Ruang lingkup lelang eksekusi diatur secara terbatas dalam Peraturan Petunjuk Lelang, yaitu antara lain lelang ekekusi putusan pengadilan, lelang eksekusi pajak, lelang eksekusi gadai, lelang jaminan fidusia, lelang hak tanggungan dan lelang eksekusi barang sitaan.

Proses pelelangan diawali dengan adanya permohonan lelang yang diajukan secara tertulis dari penjual lelang kepada Kepala Kantor Pelayanan Kekayaan Negara dan Lelang (selanjutnya disebut KPKNL) untuk mendapatkan jadwal lelang disertai dokumen persyaratan lelang. Pengertian penjual lelang dapat ditemukan dalam Pasal

\footnotetext{
${ }^{9}$ Halim, M. S. (2018). Perlindungan Hukum Terhadap Pemilik Jaminan Dalam Lelang Eksekusi Hak Tanggungan. Jurnal Hukum Bisnis Bonum Commune 1(1), 96-109. doi.org/10.30996/jhbbc.v0i0.1760, h. 96.

${ }^{10}$ Prasetyawati, N., \& Hanoraga, T. (2015). Jaminan Kebendaan Dan Jaminan Perorangan Sebagai Upaya Perlindungan Hukum Bagi Pemilik Piutang. Jurnal Sosial Humaniora 8(1).dx.doi.org/10.12962/j24433527.v8i1.1247. h.125-126.

11 Usanti, T. P. (2012). Lahirnya Hak Kebendaan. Jurnal Persepektif 17(1). doi.org/10.30742/perspektif.v17i1.93, h. 46.
} 
1 angka (19), yaitu orang, badan hukum/usaha atau instansi yang berdasarkan peraturan perundang-undangan atau perjanjian berwenang untuk menjual barang secara lelang.

Peraturan Petunjuk Lelang menentukan bahwa Penjual Lelang bertanggungjawab penuh terhadap keabsahan dokumen persyaratan lelang. Hal ini diatur secara tegas dalam Pasal 16 ayat (1) Peraturan Petunjuk Lelang. Sanksi terhadap pelanggaran ketentuan dimaksud diatur dalam Pasal 16 ayat (2) dan (3), yang mana Penjual Lelang bertanggungjawab baik secara pidana dan perdata termasuk membayar tuntutan ganti kerugian terhadap segala kerugian yang timbul akibat tidak dipenuhi ketentuan tersebut.

Dalam hal pelelangan Hak Tanggungan, maka dokumen yang harus diserahkan oleh Penjual Lelang adalah sebagai berikut:
a. Perjanjian Kredit;
b. Akta Pemberian Hak Tanggungan;
c. Sertifikat Hak Tanggungan
d. Sertifikat Hak Milik;
e. Surat teguran I, Surat teguran II dan Surat teguran III;
f. Taksiran nilai limit atas objek lelang yang dikeluarkan oleh jasa penilai independent;

Apabila permohonan lelang secara tertulis dan dokumen persyaratannya telah lengkap, maka Kepala KPKNL tidak boleh menolak permohonan lelang yang diajukan atau dengan kata lain Kepala KPKNL wajib untuk menerima dan melaksanakan permohonan lelang apabila segala persyaratan telah dipenuhi. Kewajiban ini secara tegas dinyatakan dalam Pasal 12 Peraturan Petunjuk Lelang.

Untuk pelelangan dengan objek lelang berupa tanah, surat keterangan tanah adalah satu syarat tambahan yang harus dipenuhi. Kepala KPKNL atau Pejabat Lelang Kelas II wajib untuk mendapatkan surat keterangan tanah dengan mengajukan permohonan secara tertulis ke kantor pertanahan dimana tanah itu berada.

Selanjutnya, Kepala KPKNL wajib untuk menentukan waktu dan tempat pelaksanaan lelang. Pasal 19 Peraturan Petunjuk Lelang memberikan batasan mengenai tempat pelaksanaan lelang, dimana lelang harus dilaksanakan di dalam wilayah kerja KPKNL atau wilayah jabatan Pejabat Lelang Kelas II tempat barang berada.

Setelah ada penetapan waktu dan tempat pelaksanaan lelang, maka akan dilakukan pengumuman lelang di surat kabar. Dalam pengumuman lelang akan mencantumkan informasi mengenai Penjual Lelang, Objek Lelang, nilai limit, syarat lelang dan tempat serta waktu pelaksanaan. Tujuan dari dilakukannya pengumuman lelang adalah untuk menghimpun peminat lelang dan memberitahukan adanya lelang kepada pihak yang berkepentingan. Pengumuman lelang adalah hal yang wajib dilakukan, bahkan pelanggaran terhadap pelaksanaan pengumuman lelang dapat mengakibatkan pembatalan lelang sebagaimana ditegaskan dalam Pasal 27 huruf (h) Peraturan Petunjuk Lelang.

Pihak yang berminat untuk menjadi peserta lelang wajib untuk membayar uang jaminan penawaran lelang. Lelang tetap akan dilaksanakan meskipun hanya ada 1 (satu) peserta lelang. Apabila tidak ada peserta lelang, maka lelang tetap dilaksanakan 
namun dibuatkan Risalah Lelang Tidak Ada Penawaran. Hal ini diatur dalam Pasal 4 Peraturan Petunjuk Lelang.

Setelah semua syarat terpenuhi dan ada peserta lelang, maka lelang akan dilaksanakan dan akan dibuatkan Risalah Lelang. Pengertian Risalah Lelang dapat ditemukan dalam Pasal 1 angka (32) Peraturan Petunjuk Lelang, yaitu berita acara pelaksanaan lelang yang dibuat oleh Pejabat Lelang yang merupakan akta otentik dan mempunyai kekuatan pembuktian sempurna. Risalah Lelang dibuat dalam Bahasa Indonesia dan mencantumkan proses pelelangan, mulai dari permohonan lelang, uraian mengenai barang yang dilelang, pengumuman dan penawaran lelang, Pejabat Lelang, pembeli lelang, harga lelang sampai dengan harga barang yang terjual.

Salah satu sifat dari lelang adalah lelang tidak dapat dibatalkan apabila pelaksanaannya telah sesuai dengan ketentuan yang berlaku. Hal ini diatur secara tegas dalam Pasal 3 Peraturan Petunjuk Lelang. Adapun makna dari ketentuan tersebut, barang yang sudah terjual dalam lelang harus beralih kepada pemenang lelang.

\subsection{Akibat Hukum Lelang Tanah Tanah Yang Menjadi Objek Sewa Menyewa}

Pada prinsipnya, sewa menyewa merupakan suatu perjanjian yang melahirkan perikatan antara para pihak yang membuatnya. Perikatan dapat diartikan sebagai suatu hubungan hukum antara 2 (dua) orang atau lebih dalam lapangan harta kekayaan, dimana pihak yang satu berkewajiban untuk memenuhi prestasinya kepada pihak yang lain. Dari pengertian di atas, maka perikatan hanya terbatas pada suatu hubungan hukum, yaitu hubungan yang menimbulkan akibat hukum. ${ }^{12}$ Perjanjian sewa menyewa merupakan perjanjian timbal-balik, yang artinya masing-masing pihak mempunyai kewajiban satu terhadap lainnya.

Pasal 1548 KUH Perdata memberikan pengertian sewa menyewa sebagai suatu perjanjian, dengan mana pihak yang satu mengikatkan dirinya untuk memberikan kepada pihak yang lainnya kenikmatan dari sesuatu barang, selama suatu waktu tertentu dan dengan pembayaran sesuatu harga, yang oleh pihak tersebut belakangan itu disanggupi pembayarannya.

Berdasarkan pengertian sewa menyewa menurut KUH Perdata tersebut di atas, maka unsur-unsur dalam suatu perjanjian sewa menyewa adalah sebagai berikut:

a. Adanya pemilik objek sebagai pihak yang menyewakan dan pihak penyewa;

b. Ada kesepakatan antara pihak yang menyewakan dan pihak penyewa;

c. Adanya barang yang menjadi objek sewa menyewa;

d. Adanya harga sewa;

e. Adanya kewajiban dari pihak yang menyewakan untuk menyerahkan kenikmatan kepada pihak penyewa atas suatu benda;

f. Adanya kewajiban dari penyewa untuk menyerahkan uang pembayaran kepada pihak yang menyewakan;

g. Adanya jangka waktu sewa.

12 Hernoko, A. Y. (2008). Hukum Perjanjian Azas Proporsionalitas Dalam Kontrak Komersial. Yogyakarta: Laksbang Mediatama, h. 1. 
Perjanjian sewa menyewa hanya memindahkan hak penguasaan, hak penggunaan atau hak pemanfaatan atas suatu barang selama jangka waktu tertentu dari pemilik barang/pihak yang menyewakan kepada penyewa. Jadi selama masa sewa, penguasaan atas barang yang menjadi objek sewa berada dalam penyewa, baik penguasaan yuridis maupun penguasaan secara fisik. Penguasaan yuridis dapat diartikan sebagai penguasaan atas suatu barang atau objek yang dilandasi oleh alas hak yang sah dan dilindungi oleh hukum, sedangkan penguasaan fisik adalah perbuatan menguasai dalam arti yang sebenarnya. ${ }^{13}$

Salah satu contoh sengketa yang timbul dalam perjanjian sewa menyewa adalah adanya eksekusi lelang hak tanggungan atas tanah yang terlebih dahulu telah menjadi objek dalam suatu perjanjian sewa menyewa. Permasalahan yang timbul adalah mengenai kelangsungan perjanjian sewa menyewa dan juga mengenai penyerahan dan penguasaan atas tanah.

Dalam suatu pelelangan, terdapat 2 bentuk penyerahan yang dilakukan oleh pemilik objek lelang kepada pemenang lelang, yaitu penyerahan hak kebendaan secara yuridis dan secara nyata. ${ }^{14}$ Penyerahan secara yuridis terjadi melalui proses peralihan hak dalam alas hak kepemilikan atas objek lelang, misalnya jika objek lelang berupa tanah, maka penyerahan yuridisnya dilakukan melalui proses pendaftaran hak di kantor pertanahan setempat.

Penyerahan secara yuridis harus diikuti dengan penyerahan secara nyata. Tujuan dari penyerahan secara nyata agar pihak pemenang lelang dapat menguasai dan memanfaatkan objek lelang sebagai pemilik yang baru.

Penyerahan secara nyata sangat tergantung pada itikad baik dari pemilik asal objek lelang, khususnya dalam hal objek lelang berupa tanah. Permasalahan lain akan timbul apabila ternyata tanah yang dilelang sudah menjadi objek perjanjian sewa yang dibuat jauh sebelum perjanjian kredit ada. Penyerahan secara nyata justru akan mengakibatkan kerugian pada hak-hak penyewa. Contoh nyata dari permasalahan ini adalah kasus Jerome Beckwith Forrest melawan I Gusti Ngurah Arjasa dkk yang diputus dalam Putusan Pengadilan Negeri Denpasar No. 387/Pdt.Plw/2011/PN.Dps.

Dalam kasus yang menjadi bahan dalam jurnal ini, yaitu kasus perdata pelaksanaan sewa menyewa tanah yang telah diputus sebagaimana Putusan Pengadilan Negeri Denpasar No. 387/Pdt.Plw/2011/PN.Dps, sewa menyewa yang dibuat oleh penyewa dilakukan pada tahun 2002 sedangkan perjanjian kredit yang melandasi Akta Pemberian Hak Tanggungan dibuat pada tahun 2009. Berdasarkan hal tersebut maka diketahui jika tanah yang menjadi objek lelang terlebih dahulu tunduk pada perjanjian sewa menyewa.

Dalam suatu perjanjian, jika salah satu pihak berjanji dan mengikatkan diri kepada pihak yang lain untuk melakukan atau memberikan sesuatu, maka dalam diri pihak yang menerima janji tersebut telah lahir suatu hak. Jadi apabila janji tersebut dilanggar, maka akan menimbulkan kerugian pada pihak lain.

\footnotetext{
${ }^{13}$ Harsono, B. (2003). Hukum Agraria Indonesia, Sejarah Pembentukan Undang-Undang Pokok Agraria. Jakarta: Djambatan, h. 23.

${ }^{14}$ Sianturi, P. T. (2008). Perlindungan Hukum Terhadap Pembeli Barang Jaminan Tidak Bergerak Melalui Lelang. Bandung: Mandar Maju, h. 114-115.
} 
Selain itu, aturan dalam Pasal 1576 KUH Perdata juga melindungi kepentingan penyewa. Pasal tersebut menentukan bahwa "Dengan dijualnya barang yang disewa, suatu persewaan yang dibuat sebelumya tidak diputuskan kecuali apabila ini telah diperjanjikan pada waktu menyewakan barang". Ketentuan ini mempunyai makna apabila terjadi peralihan hak atas benda yang menjadi objek dari suatu perjanjian sewa menyewa kepada pihak ketiga, maka perjanjian sewa menyewa yang sudah terjadi sebelumnya tidak serta merta putus atau berakir, melainkan tetap berlangsung kecuali hal tersebut telah diperjanjikan sebelumnya.

Pada prinsipnya suatu pelanggaran terhadap kewajiban yang telah ditetapkan dalam perjanjian dapat dikategorikan sebagai perbuatan wanprestasi. Ada 3 (tiga) wujud dari wanprestasi, yaitu:

a. Debitor tidak memenuhi kewajibannya;

b. Debitor terlambat dalam memenuhi kewajibannya; dan

c. Debitor memenuhi kewajiban namun tidak sesuai dengan apa yang diperjanjikan.

Apabila dari pelelangan tersebut ada hak penyewa yang dirugikan maka penyewa dapat mengajukan upaya hukum untuk mempertahankan hak-haknya. Upaya hukum yang bisa diambil oleh penyewa sebagai pihak yang dirugikan adalah dengan mengajukan suatu tuntutan hak atau gugatan contentiosa ke pengadilan. Gugatan pada umumnya didasarkan pada 2 (dua) hal, yaitu adanya wanprestasi oleh satu pihak dalam pelaksanaan perjanjian dan adanya perbuatan melawan hukum yang menimbulkan kerugian bagi orang lain.

Upaya hukum lain yang dapat diambil oleh penyewa adalah dengan mengajukan gugatan perlawanan pihak ketiga. Perlawanan pihak ketiga atau derden verzet diatur dalam Pasal 378 Reglement op de Rechtvordering (Rv) yang juga merupakan salah satu sumber hukum acara perdata di Indonesia. Derden verzet ini dapat diartikan sebagai suatu tuntutan hak yang diajukan pihak ketiga apabila ada hak-haknya yang secara nyata dirugikan oleh suatu putusan atau penetapan pengadilan.

Derden verzet ini merupakan salah satu bentuk upaya hukum luar biasa karena perlawanan pihak ketiga ini dapat menunda pelaksanaan eksekusi. Dalam praktek terdapat 2 (dua) macam perlawanan pihak ketiga, yaitu:

a. Perlawanan pihak ketiga terhadap sita eksekusi.

b. Perlawanan pihak ketiga terhadap sita jaminan.

Perlawanan pihak ketiga (derden verzet) terhadap sita eksekusi pengadilan adalah perlawanan pihak ketiga atas suatu pelaksanaan putusan atau penetapan dari pengadilan. Perlawanan pihak ketiga ini digolongkan sebagai upaya hukum luar biasa karena sifatnya merupakan upaya hukum terhadap putusan yang telah berkekuatan hukum tetap bahkan dapat menunda pelaksanaan eksekusi tersebut.

Dalam kaitannya dengan objek lelang telah menjadi objek perjanjian sewa menyewa sebelum pelelangan terjadi, maka hak-hak penyewa harus tetap dihormati dan perjanjian sewa menyewa masih tetap berlaku sampai berakhirnya masa sewa, kecuali ditentukan lain dalam perjanjian. Namun demikian, tidak menutup kemungkinan timbul suatu kerugian yang dialami oleh penyewa akibat pelelangan tersebut dan 
terhadap adanya kerugian tersebut, maka penyewa dapat menempuh upaya gugatan perlawanan ke pengadilan untuk mempertahankan hak-haknya.

\section{Kesimpulan}

Berdasarkan pembahasan di atas, dapat disimpulkan bahwa suatu pelelangan eksekusi hak tanggungan didahului oleh adanya permohonan tertulis dari kreditor yang disertai dokumen-dokumen kelengkapan yang menjadi persyaratannya. Apabila persyaratan dipenuhi, maka Kepala Kantor Pelayanan Kekayaan Negara dan Lelang wajib untuk mengabulkan permohonan dan mengumumkan syarat, waktu dan tempat pelaksanaan lelang di surat kabar. Setiap pelaksanaan lelang akan dibuatkan Risalah Lelang yang menguraikan proses pelelangan dari diajukannya permohonan sampai dengan pelaksanaan lelang. Lelang yang sudah dilaksanakan tidak dapat dibatalkan sepanjang telah memenuhi syarat dan ketentuan yang ditetapkan.

Akibat hukum dari adanya pelelangan tanah yang terlebih dahulu telah menjadi objek perjanjian sewa menyewa daripada perjannjian kredit adalah tidak dapat membatalkan perjanjian sewa menyewa, sehingga perjanjian sewa menyewa tetap berlaku sampai dengan masa sewa berakhir. Suatu peralihan hak atas tanah tidak akan membatalkan atau memutus suatu perjanjian sewa, kecuali hal tersebut telah diperjanjikan sebelumnya. Penyewa yang merasa dirugikan haknya atas adanya peralihan hak dimaksud, dapat mengajukan gugatan perdata ke pengadilan yang bentuknya disesuaikan dengan peristiwa hukum yang dialami.

\section{Daftar Pustaka}

Buku

Harsono, B. (2003). Hukum Agraria Indonesia, Sejarah Pembentukan Undang-Undang Pokok Agraria. Jakarta: Djambatan.

Hartono, C.F.G. Sunaryati. (2006). Penelitian Hukum di Indonesia Pada Akhir Abad Ke-20. Bandung: Alumni.

Hernoko, A. Y. (2008). Hukum Perjanjian Azas Proporsionalitas Dalam Kontrak Komersial. Yogyakarta: Laksbang Mediatama.

Sianturi, P. T. (2008). Perlindungan Hukum Terhadap Pembeli Barang Jaminan Tidak Bergerak Melalui Lelang. Bandung: Mandar Maju.

Sjahdeini, S. R. (1996). Hak tanggungan: asas-asas, ketentuan-ketentuan pokok, dan masalahmasalah yang dihadapi oleh perbankan: suatu kajian mengenai Undang-Undang Hak Tanggungan. Airlangga University Press.

\section{Jurnal}

Halim, M. S. (2018). Perlindungan Hukum Terhadap Pemilik Jaminan Dalam Lelang Eksekusi Hak Tanggungan. Jurnal Hukum Bisnis Bonum Commune 1(1),96-109. https://doi.org/10.30996/jhbbc.v0i0.1760

Pertiwi, D. (2013). Perlindungan Hukum Pemegang Hak Tanggungan Yang Obyeknya Dikuasai Pihak Ketiga Berdasarkan Perjanjian Sewa Menyewa. Calyptra, 2(2), 116.

Prasetyawati, N., \& Hanoraga, T. (2015). Jaminan Kebendaan Dan Jaminan Perorangan Sebagai Upaya Perlindungan Hukum Bagi Pemilik Piutang. Jurnal Sosial Humaniora 8(1). https://dx.doi.org/10.12962/j24433527.v8i1.1247 
Sancaya, I. W. W. (2013). Kekuatan Mengikat Perjanjian Nominee Dalam Penguasaan Hak Milik Atas Tanah. Jurnal Magister Hukum Udayana 2(3). https://doi.org/10.24843/IMHU.2013.v02.i03.p10

Sudirga, I. M. (2017). Pelaksanaan Perjanjian Tanah Hak Milik Bersama Sebagai Agunan Dalam Kredit Di Bank Berdasarkan Undang-Undang Nomor 4 Tahun 1996 tentang Hak Tanggungan Atas Tanah Beserta Benda-Benda Yang Berkaitan Dengan Tanah. Jurnal Magister Hukum Udayana 6(2). https://doi.org/10.24843//MHU.2017.v06.i02.p10

Sumiasi, P. (2013). Penarikan Barang Yang Menjadi Objek Sewa Beli Dalam Hal Pembeli Sewa Wanprestasi. Jurnal Magister Hukum Udayana 2(3). https://doi.org/10.24843/JMHU.2013.v02.i03.p06

Usanti, T. P. (2012). Lahirnya Hak Kebendaan. Jurnal Persepektif 17(1), 44-53.

\section{$\underline{\text { Tesis }}$}

Prahandari, N. M. I. (2014). Penguasaan Hak Milik Atas Tanah Milik Warga Indonesia Oleh Warga Negara Asing Dengan Akta Notaris/Pejabat Pembuat Akta Tanah (Studi Kasus). Tesis, Program Pasca Sarjana Magister Kenotariatan, Universitas Udayana. 